\title{
OUR EXPERIENCE WITH MAGERL'S MODIFIED TECHNIQUE FOR STABILIZATION OF SUBAXIAL CERVICAL SPINE
}

\author{
Haritonov Dimitar, ${ }^{1}$ Kalevski Svetoslav, ${ }^{1,2}$ Peev Nikolay ${ }^{1}$ \\ ${ }^{1}$ University Hospital “St. Anna“, Department of Neurosurgery, Varna, Bulgaria \\ ${ }^{2}$ University of Varna, School of Medicine Varna, Bulgaria
}

Primljen/Received 26. 01. 2015. god.

Abstract: Aim: There are different surgical techniques for massa lateralis screw instrumentation of subaxial cervical spine - those of Roy-Camille, Magerl, Anderson, and An. Each has different starting point and trajectorys of screw implantation.For each technique there is a potential risk to affect vascular and neural structures.In this paper we share our experience in using a modified Magerl's technique for stabilization of subaxial cervical spine.

Method: We present a retrospective study and clinical follow-up of 27 patients operated on the occasion of cervical injury that we have used the modified technique of Magerl. In 8 patients was carried and an anterior decompression and stabilization.

Results: In these patients was carried posterior or combined - posterior and anterior stabilization. The posterior fixation was massa lateralis with this modified technique of Magerl with multiaxial screws. With this technique were inserted 160 multiaxial screws and the most common length of the implants were $108 \mathrm{~mm}$ (108 from 160 or $67.5 \%$ ).

Conclusion: Based on world literature, experience and analysis of clinical cases, we believe that this modified technique for subaxial cervical fixation is effective (the pull-out strength approach to the strength of pedicle screw instrumentation) and is much safer.

Key words: Posterior subaxial instrumentation, Magerl's technique, suaxial instability.

\section{INTRODUCTION}

Various techniques and instrumentations are available for the posterior stabilization of subaxial cervical spines after extensive decompressive surgery or trauma-related instability. These include wiring, placement of Halifax clamps, and use of various kinds of
Prihvaćen/Accepted 15. 03. 2015. god.

screws with plates or rods (1-5) and the combination of hooks and plates (6). Each of these techniques, however, presents its own limitations (7). Wiring is used less and less because it can only be carried out where certain key parts of the posterior element of the subaxial spine are present; therefore, it is impossible in most scenarios where laminectomies have been required for decompression or exposure of target lesions. Moreover, wiring provides less fixation strength in comparison with other rigid instrumentations. Halifax clamps may provide better fixation strength than wiring but are still not optimal. Lateral mass screws with plate fixation require precise contour tailoring for each patient and are thus extremely difficult for practical application. Recently, the use of lateral mass screws fixation in conjunction with rod systems has greatly increased because this technique can avoid the above-mentioned shortcomings. For examples, lateral mass screw fixation can be performed after laminectomies, and it is also applicable in extension to the occiput or the thoracic spines, and in multilevel placement with biomechanical superiority $(8,9)$. Various authors such as Magerl (6), Roy-Camille (10, 11), Anderson (3), Louis (12), and An (13) have developed different methods of placing screws into the lateral mass. However, each of these methods has carried the risk of potential injury to the neural or vascular structures due to the anatomical variations among different levels of the cervical spine and different patients. To overcome these ongoing problems, we have developed a modified technique to minimize iatrogenic neurovascular injuries while achieve maximal purchase of the screw on the bone. The pathologic features, surgical indications, surgical results, and complications of the 27 patients, treated with the modified techniques, were presented. More than half of the patients treated with skipped level fixation were also presented and discussed. 


\section{MATERIAL AND METHODS}

We present a retrospective study and clinical follow-up of 27 patients operated on the occasion of cervical injury that we have used the modified technique of Magerl. In 8 patients was carried and an anterior decompression and stabilization. In all cases is used preoperative CT and MRI of the subaxial cervical spine (C3-C7) for assessment of anatomical peculiarities and measurements, postoperative $\mathrm{CT}$ to assess the position of the implants, pre- and postoperative NDI score were used as instruments for assessment. In these patients was carried posterior or combined - posterior and anterior stabilization. The posterior fixation was massa lateralis with this modified technique of Magerl with multiaxial screws. With this technique were inserted 160 multiaxial screws and the most common length of the implants were $16 \mathrm{~mm}$ [108 from 160 or $67,5 \%$ ]. The screws with length of $14 \mathrm{~mm}-30$ or $18,75 \%$ and $18 \mathrm{~mm}$ screws were implanted 22 or 13,75\% (figure 1 and 2).

\section{Results:}

The mean follow up period was 15 months (4-35 months). A total of 160 screws were used in 27 patients placing into the lateral masses of the subaxial cervical spine from $\mathrm{C} 3$ including $\mathrm{C} 6$. Of which 24 screws were placed on $\mathrm{C} 3$ level, 58 were placed on $\mathrm{C} 4$ and $\mathrm{C} 5$ levels and 20 were placed on C6 level (Figure 2). The most frequently used screw were $16 \mathrm{~mm}$ in length (Figure 1). The levels $\mathrm{C} 4$ and $\mathrm{C} 5$ received a greater percentage of longer screws. No newly developed neurologic deficits occurred after surgery. Neither spinal cord injuries nor spinal nerve root injuries were observed postoperatively. We seldom encountered excessive haemorrhaging during screw placement. None of these 27 patients experienced any postoperative ischemic neurologic symptoms, especially those involving posterior circulation such as vertigo, dizziness or vomiting. No verte-

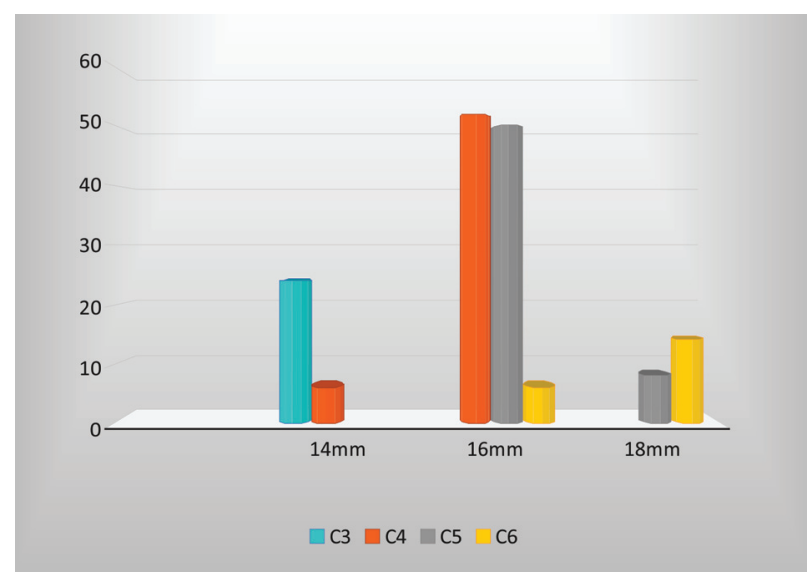

Figure 1. Distribution of the cervical levels and length of implants

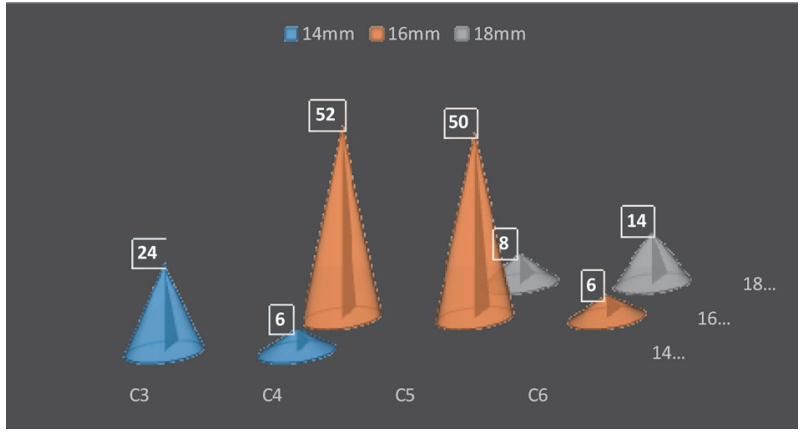

Figure 2. Distribution of the cervical levels and length of implants

bral artery injury was encountered. Radiography taken at 8-12 weeks after operative procedure, when hard cervical collar was taken away, revealed that most patients had substantial bone fusion. The stability was further confirmed by dynamic lateral radiography (flexion/extension). Although it is difficult to ensure complete bone fusion. No instrumentation failure has been observed with the longest follow-up time 35 months, except one patient who did develop secondary kyphotic deformity and screws self-pulled out, which was demonstrated on lateral radiography 3 months after operation.

\section{DISCUSSION}

Lateral mass plating has been the procedure of choice in the past decade in posterior cervical fixation $(14,15)$. Butthere are at least 4 drawbacks of such instrumentation (4). First, plates are difficult to contour, especially in cases of severe deformity associated with spondylosis or trauma. Second, the fixed hole spacing of the plate significantly limits screw positioning. It may make the entry point of lateral mass screws become less ideal. Some levels of the cervical spine cannot but omit from plating because the plate's fixed hole does not fit for screw placement at that particular level. This limitation is especially obvious when longer constructs are required. Third, it is difficult to adapt the plate system for fusion up to the occiput or down to the thoracic spine. Fourth, postoperative radiculopathy is likely to occur because of the lag screw effect (16), in which there is a risk of iatrogenic foraminal stenosis where the plating system has been used. Precise contouring can be easily achieved with rod systems than that of using plate system. Therefore, the use of rod system with lateral mass screws has become more popular. Some encouraging results using rod system have been reported $(5,17)$. Our experience with lateral mass screws and rod systems is compatible with these recent findings. And the usage of polyaxial screw with rods is becoming the principal device of choice for posterior stabilization of cervical spine, especially when upward or downward extension is required (18). 


\section{MODIFIED SURGICAL TECHNIGUES}

There are many techniques for placing lateral mass screws, as described by several authors such as Magerl (6), Anderson (3, 18), An (12), and Roy-Camille (10). The principal complications caused by malpositioned screws are violation of vertebral arteries and cervical nerve root injury (19). Many authors (19-23) have conducted anatomical studies to clarify the pros and cons of each method of screw placement. In 1995, Pait and al (24) divided the lateral cervical mass (articular pillars of the cervical spine) into quadrants and concluded that the superior lateral quadrant was the "safe quadrant" for placing screws. In 2002, Merola and colleagues (22) came to a similar conclusion: that aiming at the superior-lateral corner of the lateral mass itself offers the maximum amount of bone for screw purchase. Xu and his colleagues (19) found in 1999 that the potential risk for nerve root violation is lower for the An technique than the Magerl and Anderson technique. In 2005, Barrey and colleagues (20) found the

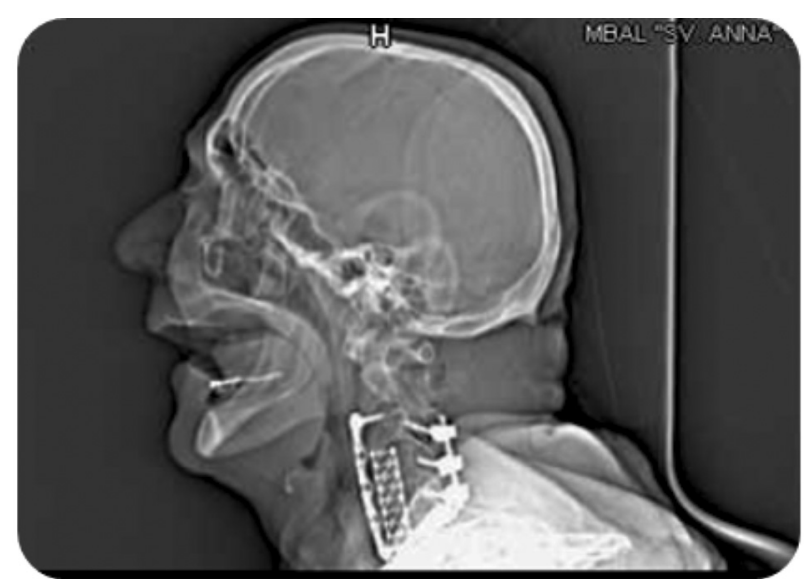

Figure 3. A $360^{\circ}$ cervical fixation

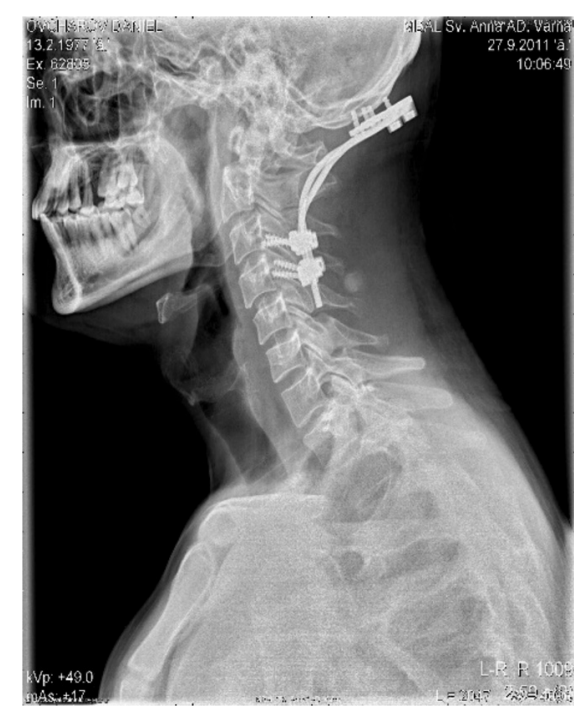

Figure 4. Occipitospinodesis (C3-C4 massa lateralis/occiput)
Roy-Camille technique is the best option for $\mathrm{C} 3$ and $\mathrm{C} 4$, whereas the Magerl technique is a safer, although more demanding, procedure for $\mathrm{C} 5$ and $\mathrm{C} 6$. We try to develop a simple and uniform method for placing lateral mass screws from $\mathrm{C} 3$ to $\mathrm{C} 7$, by proposing a modification technique that shifted the screw entry point to $1.5 \mathrm{~mm}$ medial and inferior to the geometry center of the lateral mass surface (Figure 3 and 4). The screw trajectory, which aims at its superior lateral quadrant, is modified from theAn, Anderson, and Magerl techniques. Our entry point selection combined with the trajectory allows to aim at the "safe quadrant". This usually requires longer screws because of the longer path in the lateral mass. Thus, the screw length most often used in our series was $16 \mathrm{~mm}$ long, compared with the 14-mm screws used by Sekhon (25) in 2005. One potential drawback of this modified technique isthat if the entry point is not low enough or if the sagittal trajectory is made too steep, the overlying surface of the lateral mass could possibly break, thus making it impossible to place the screws (26-30). Nevertheless, the mainstay of this modification is that the surgeon is able to accurately estimate the depth and height of the unexposed superior lateral corner in conjunction with a proper entry point.

\section{Comparison with other techniques of lateral mass screw insertion:}

This modification techniques of screw placement techniques consisted of a more angulated trajectory, with a modified entry point. The entrance point we chose was more caudally and medially located, thus allowing a longer tract inside lateral mass to maximize the screw purchase. The Roy-Camille technique may represent another end of the spectrum for the ideal tip position, given that it comprises a completely different screw trajectory that is nearly perpendicular to the horizon, with a centered entry point (Figure 5 and 6). One of the main reasons that we are able to follow such a greatly angulated trajectory is the development of polyaxial screws. It made possible to place the screw toward the superior-lateral-ventral corner of the lateral mass, with ease of construction with rods.
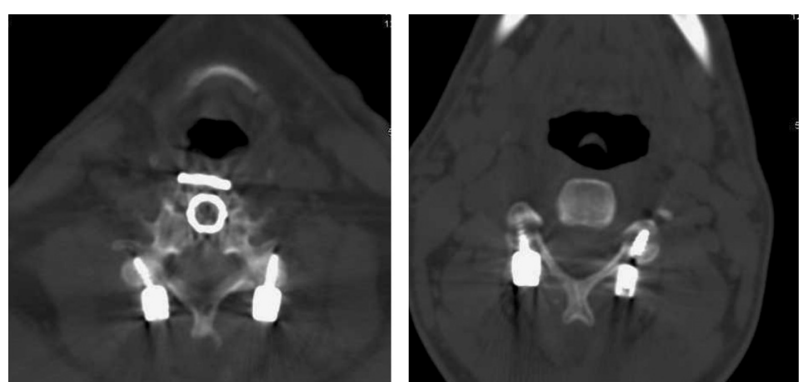

Figure 5. Proper position of implants - CT axial image 


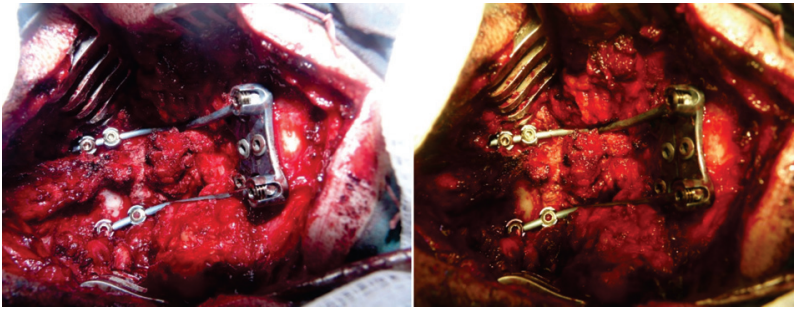

Figure 6. Intraoperative image - occiput/massa lateralis instrumentation

The longer screw purchase with more angulated trajectory might account for the low rate of screw pullout in our series. The risks of vascular and neuralinjury with the longer screws could be reduced by placing their tips in the ideal position, the superior-lateral-ventral corner of the lateral mass (31-36).

\section{CONCLUSION}

The results of our study indicate that lateral mass screw fixation is safe and cost-effective for stabilization of the subaxial cervical spine, including those with skipped level fixation. Our modified entrance point and screw trajectory are believed to be a good alternative comparable to other reported methods of screw placement. More biomechanical studies of such technique and longer follow-up time are required to confirm the value and satisfactory results of our modified technique.

\title{
Sažetak
}

\section{NAŠE ISKUSTVO SA MAGERL-OVOM MODIFIKOVANOM TEHNIKOM ZA STABILIZACIJU SUBAKSIJALNE CERVIKALNE KIČME}

\author{
Haritonov Dimitar, ${ }^{1}$ Kalevski Svetoslav, ${ }^{1,2}$ Peev Nikolay ${ }^{1}$ \\ ${ }^{1}$ University Hospital "St. Anna“, Department of Neurosurgery, Varna, Bulgaria \\ ${ }^{2}$ University of Varna, School of Medicine Varna, Bulgaria
}

Cilj: Postoje različite hirurške tehnike za plasiranje spoljašnjih šrafova kod povreda subaksijalne vratne kičme — Roy-Camille, Magerl, Anderson i An tehnike. Svaka od njih ima drugačiju početnu tačku i putanju impalntacija šrafa. Za svaku tehniku postoji potencijalni rizik za povredu vaskularnih i nervnih struktura. U ovom radu izlažemo naše iskustvo sa upotrebom modifikovane Magrel-ove tehnike za stabilizaciju subaksijalne vratne kičme.

Metod: Ovom retrospektivnom studijom prikazano je kliničko praćenje 27 pacijenata operisanih zbog povrede vratne kičme kod kojih smo koristili modifikovanu Megerl-ovu tehniku. Kod 8 pacijenata primenjena je i prednja dekompresija i stabilizacija.

\section{REFERENCES}

1. Abumi K, Kaneda K. Pedicle screw fixation for nontraumatic lesions of the cervical spine. Spine. 1997; 22(16): 1853-63.

2. Abumi K, Kaneda K, Shono Y, Fujiya M. One-stage posterior decompression and reconstruction of the cervical spine by using pedicle screw fixation systems. J Neurosurg. 1999; 90 (1 Suppl): 19-26.

3. Anderson PA, Henley MB, Grady MS, Montesano PX, Winn HR. Posterior cervical arthrodesis with AO reconstruction plates and bone graft. Spine. 1991; 16 (3 Suppl): S72-9.

4. Deen HG, Birch BD, Wharen RE, Reimer R. Lateral mass screw-rod fixation of the cervical spine: a prospective clinical series with 1-year followup. Spine J. 2003; 3 (6): 489-95.

5. Horgan MA, Kellogg JX, Chesnut RM. Posterior cervical arthrodesis and stabilization: an early report using a novel la-
Rezultati: Kod ovih pacijenata primenjena je zadnja ili kombinovana - zadnja i prednja stabilizacija. Zadnja fiksacija je bila massa lateralis sa modifikovanom Megerl-ovom tehnikom sa multiaksijalnim šrafovima. Ovo tehnikom plasirano je 160 multiaksijalnih šrafova i najčešća dužina implanta bila je 108 mm (108 od 160 ili $67.5 \%$ ).

Zaključak: Na osnovu svetske literature, iskustva i analize kliničkih slučajeva, verujemo da je ova modifikovana tehnika subaksijalne cervikalne fiksacije efektivna i mnogo sigurnija.

Ključne reči: Zadnja aksijalna instrumentacija, Magerl-ova tehnika, subasijalna nestabilnost.

teral mass screw and rod technique. Neurosurgery. 1999; 44 (6): $1267-71$

6. Jeanneret B, Magerl F, Ward EH, Ward JC. Posterior stabilization of the cervical spine with hook plates. Spine. 1991; 16 (3 Suppl): S56-63.

7. Gill K, Paschal S, Corin J, Ashman R, Bucholz RW. Posterior plating of the cervical spine. A biomechanical comparison of different posterior fusion techniques. Spine. 1988; 13 (7): 813-6.

8. Shapiro S, Snyder W, Kaufman K, Abel T. Outcome of 51 cases of unilateral locked cervical facets: interspinous braided cable for lateral mass plate fusion compared with interspinous wire and facet wiring with iliac crest. J Neurosurg. 1999; 91 (1 Suppl): 19-24.

9. Ulrich C, Arand M, Nothwang J. Internal fixation on the lower cervical spine - biomechanics and clinical practice of procedures and implants. Eur Spine J. 2001; 10(2): 88-100. 
10. Roy-Camille R, Saillant G, Laville C, Benazet JP. Treatment of lower cervical spinal injuries - C3 to C7. Spine. 1992; 17(10 Suppl): S442-6.

11. Nazarian SM, Louis RP. Posterior internal fixation with screw plates in traumatic lesions of the cervical spine. Spine. 1991; 16 (3 Suppl): S64-S71.

12. An HS, Gordin R, Renner K. Anatomic considerations for plate-screw fixation of the cervical spine. Spine. 1991; 16(10 Suppl): S548-51.

13. Graham AW, Swank ML, Kinard RE, et al. Posterior cervical arthrodesis and stabilization with a lateral mass plate. Clinical and computed tomographic evaluation of lateral mass screw placement and associated complications. Spine. 1996; 21(3): 323-8 [discussion 9].

14. Swank ML, Sutterlin III CE, Bossons CR, Dials BE. Rigid internal fixation with lateral mass plates in multilevel anterior and posterior reconstruction of the cervical spine. Spine. 1997; 22 (3): 274-82.

15. Heller JG, Silcox III DH, Sutterlin III CE. Complications of posterior cervical plating. Spine. 1995; 20 (22): 2442-8.

16. Mummaneni PV, Haid RW, Traynelis VC, et al. Posterior cervical fixation using a new polyaxial screw and rod system: technique and surgical results. Neurosurg Focus. 2002; 12 (1): E8.

17. Horn EM, Hott JS, Porter RW, Theodore N, Papadopoulos SM, Sonntag VK. Atlantoaxial stabilization with the use of C1-3 lateral mass screw fixation. Technical note. J Neurosurg Spine. 2006; 5 (2): 172-7.

18. Anderson PA, Budorick TE, Easton KB, Henley MB, Salciccioli GG. Failure of halo vest to prevent in vivo motion in patients with injured cervical spines. Spine. 1991; 16 (10 Suppl): S501-5.

19. Xu R, Haman SP, Ebraheim NA, Yeasting RA. The anatomic relation of lateral mass screws to the spinal nerves. A comparison of the Magerl, Anderson, and An techniques. Spine. 1999; 24 (19): 2057-61.

20. Barrey C, Mertens P, Jund J, Cotton F, Perrin G. Quantitative anatomic evaluation of cervical lateral mass fixation with a comparison of the Roy-Camille and the Magerl screw techniques. Spine. 2005; 30 (6): E140-7.

21. Chin KR, Eiszner JR, Roh JS, Bohlman HH. Use of spinous processes to determine drill trajectory during placement of lateral mass screws: a cadaveric analysis. J Spinal Disord Tech. 2006; 19 (1): 18-21.

\author{
Correspondence to/Autor za korespondenciju \\ Dimitar Haritonov \\ Bul. Tzar Osvoboditel N100 \\ 9000 Varna, Bulgaria \\ Department of Neurosurgery \\ University Hospital St. Anna Varna \\ dharitonov@haritonov.eu \\ +359888313357
}

22. Merola AA, Castro BA, Alongi PR, et al. Anatomic consideration for standard and modified techniques of cervical lateral mass screw placement. Spine J. 2002; 2 (6): 430-5.

23. Xu R, Ebraheim NA, Nadaud MC, Yeasting RA, Stanescu S. The location of the cervical nerve roots on the posterior aspect of the cervical spine. Spine. 1995; 20(21): 2267-71.

24. Pait TG, McAllister PV, Kaufman HH. Quadrant anatomy of the articular pillars (lateral cervicalmass) ofthecervicalspine. J Neurosurg. 1995; 82 (6): 1011-4.

25. Sekhon LH. Posterior cervical lateral mass screw fixation: analysis of 1026 consecutive screws in 143 patients. J Spinal Disord Tech. 2005; 18(4): 297-303.

26. Abumi K, Shono Y, Ito M, Taneichi H, Kotani Y, Kaneda K. Complications of pedicle screw fixation in reconstructive surgery of the cervical spine. Spine. 2000; 25 (8): 962-9.

27. Abumi K, Shono Y, Taneichi H, Ito M, Kaneda K. Correction of cervical kyphosis using pedicle screw fixation systems. Spine. 1999; 24(22): 2389-96.

28. Albert TJ, Vacarro A. Postlaminectomy kyphosis. Spine 1998; 23(24): 2738-45.

29. Brodke DS, Bachus KN, Mohr RA, Nguyen BK. Segmental pedicle screw fixation or cross-links in multilevel lumbar constructs. A biomechanical analysis. Spine J. 2001; 1(5): 373-9.

30. Dick JC, Zdeblick TA, Bartel BD, Kunz DN. Mechanical evaluation of cross-link designs in rigid pedicle screw systems. Spine. 1997; 22(4): 370-5.

31. Hart R, Hettwer W, Liu Q, Prem S. Mechanical stiffness of segmental versus nonsegmental pedicle screw constructs: the effect of cross-links. Spine. 2006; 31(2): E35-8.

32. Kast E, Mohr K, Richter HP, Börm W. Complications of transpedicular screw fixation in the cervical spine. Eur Spine J. 2006; 15(3): 327-34.

33. Kotani Y, Abumi K, Ito M, Minami A. Improved accuracy of computerassisted cervical pedicle screw insertion. J Neurosurg. 2003; 99(3 Suppl): 257-63.

34. Pateder DB, Carbone JJ. Lateral mass screw fixation for cervical spine trauma: associated complications and efficacy in maintaining alignment. Spine J. 2006; 6(1): 40-3.

35. Roche S, de Freitas DJ, Lenehan B, Street JT, McCabe JP. Posterior cervical screw placement without image guidance: a safe and reliable practice. J Spinal Disord Tech. 2006; 19(6): 383-8.

36. Valdevit A, Kambic HE, McLain RF. Torsional stability of cross-link configurations: a biomechanical analysis. Spine J. 2005; 5(4): 441-5. 